\section{How much is really changing in Japan?}

\author{
Japanese Science: From \\ the Inside \\ by Samuel Coleman \\ Routledge: 1999. 214 pp. \$90, £55
}

\section{Robert TriendI}

John Desmond Bernal, the noted crystallographer and vigorous social critic, had little good to say about Japanese science. His verdict, published in his book The Social Function of Science (Routledge, 1939), was devastating. For Bernal, Japanese science was hopelessly inaccurate, bureaucratic and misguided by political ideology. Since he was writing in 1939, though, his judgement is perhaps better understood as a reflection of antagonism towards an expansionist military power. In fact, by that time, Japanese scientists had made important contributions in various disciplines.

Japanese science has come even further since then. After almost three decades of darkness and severe material limitations following the Second World War, funding for research has soared. Today, Japanese laboratories are among the best-equipped in the world and there can be little doubt that Japan matters in virtually any field of science and technology. Yet it is not unusual to hear Japanese scientists describing the reality in terms that differ little from Bernal's harsh assessment of more than 60 years ago.

In Japanese Science: From the Inside, the American anthropologist Samuel Coleman provides a profound and insightful critique of scientific organizations in Japan. The book is based on extensive fieldwork in a number of bioscience-related laboratories and research institutes. And, most importantly, rather than rushing towards his own judgements, Coleman provides ample space for the views and voices of Japanese researchers themselves.

Complaints about bureaucratic rigidity abound in Japan, and the degree of frustration in some quarters, especially among young scientists, is alarmingly high. If one is to believe grass-roots polls undertaken in anonymity by academic societies, most scientists in the country believe that promotion has more to do with personal connection than with individual achievements, and that the evaluation procedures of the Ministry of Education's US $\$ 2$ billion university grants system is seriously flawed.

The vast majority of basic science is undertaken in national universities and it is there that most of the problems lie. Hiring and promotion practices remain largely obscure, access to resources remains under the control of a few senior professors at major

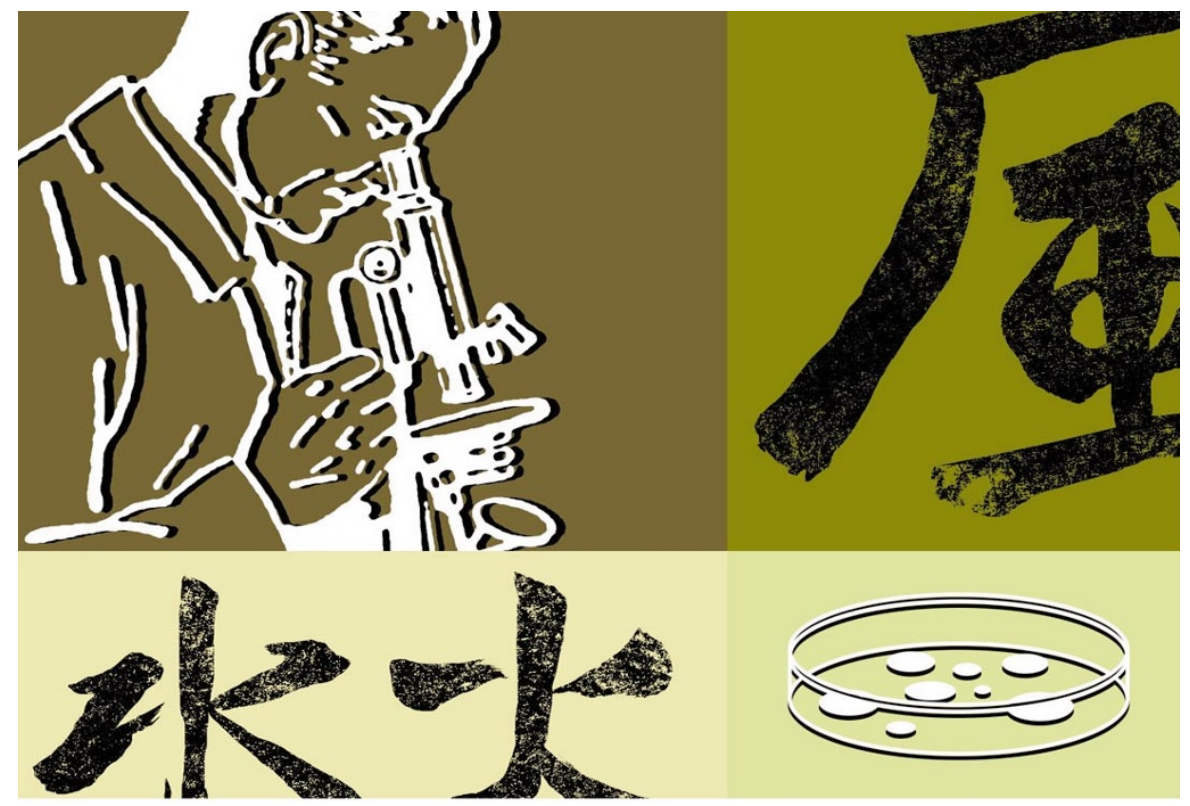

national universities, and administrative rules strangle university research.

It is telling that no Japanese university ever offered a professorship to Shuji Nakamura, who pioneered research on gallium nitride semiconductors while working for a local manufacturer of fluorescent materials. Japanese national universities remain 'closed shops' not only to foreigners and the growing number of female researchers, but also to anybody outside the academic networks of power. Japanese scientists who trained overseas often find it difficult to integrate into the Japanese academic community.

While Coleman's book is a devastating assessment of the scientific enterprise in Japan, he does not derive his conclusion from simple comparisons with elsewhere. Instead, he looks at disruptions to what Bruno Latour and Steve Woolgar in their study Laboratory Live have called the "cycle of credibility" (Coleman terms it the "cycle of credit"), the cumulative process by which research output is translated into resources for future scientific work. Coleman makes few assumptions about how efficient scientific organizations are meant to be, as long as there are no major distortions of the credit cycle of scientific work.

Coleman has done fieldwork in a number of settings - from an application-oriented research institute under the Ministry of Agriculture to a laboratory in the medical school of a national university. But he has spent most of his time at two neighbouring institutions in Osaka: the Osaka Bioscience Institute (OBI) and the Protein Engineering Research Institute (PERI), both considered major organizational innovations in Japanese public research.

PERI and OBI are unusual in that, from the start, only limited-term positions were offered. Although these institutions were intended as show-pieces of a changing Japan, their limited-term policy created problems in the country's inflexible academic labour market, confronting scientists with the rigidities of the Japanese academic world in a sometimes shocking way. Most researchers, Coleman tells us, were there because they "had nowhere else to go" - they had unusual backgrounds or were pursuing research topics that didn't fit in with established academic career trajectories. At PERI and OBI they found a formidable research environment and unprecedented levels of support, but were locked into a somewhat unreal position that offered little except good conditions. Without much prospect of a position that would allow them to continue research, for some their assignment at PERI or OBI was little short of a moratorium.

Questions that affect the whole Japanese scientific community have taken on more articulate forms within these two institutions, but Coleman does not ignore conventional research settings. Novel arrangements such as those at PERI and OBI have made new career trajectories possible, although how much flexibility they have added to the Japanese public research system is difficult to evaluate. Considering their limited number, it is hard to reject arguments that they have simply weakened the demand for more profound reforms.

Japanese reformers are currently trying to increase job flexibility and prioritize funding. Coleman's book should be a warning to those who think that increased labour mobility in the lower ranks of the academic workforce will be sufficient to rework Japan's scientific enterprise. As long as other elements of the credit cycle - most notably evaluation and hiring practices - remain unchanged, the outcome could well be detrimental. Technology Information Program, 6-15-21 Roppongi, Minato-ku, Tokyo 106-0032, Japan. Robert Triendl is in the Tokyo office of the Asian 